\title{
Maternal and Cord Blood Levels of Serum Amyloid A, C-Reactive Protein, Tumor Necrosis Factor- $\alpha$, Interleukin-1 $\beta$, and Interleukin-8 During and After Delivery
}

\author{
Luciane Marzzullo Cicarelli, ${ }^{1,2}$ Adriana Guimarães Perroni, ${ }^{2}$ Marcelo Zugaib, ${ }^{3}$ \\ Paulo Basto de Albuquerque, ${ }^{2}$ and Ana Campa ${ }^{1}$ \\ ${ }^{1}$ Departamento de Análises Clínicas e Toxicológicas, Faculdade de Ciências Farmacêuticas, \\ Universidade de São Paulo, SP-CEP 05508-900, Brazil \\ ${ }^{2}$ Hospital Universitário, Universidade de São Paulo, SP-CEP 05508-900, Brazil \\ ${ }^{3}$ Departamento de Obstetrícia e Ginecologia, Faculdade de Medicina, \\ Universidade de São Paulo, SP-CEP 01246-903, Brazil
}

Received 23 November 2004; accepted 17 December 2004

\begin{abstract}
C-reactive protein (CRP) and serum amyloid A (SAA) are acute-phase proteins mainly synthesized by the liver in response to some cytokines. They are potentially useful to diagnosing infection and monitoring different clinical conditions. The aim of this study was to measure SAA and CRP in maternal and cord blood during and after delivery and try to correlate these proteins with tumor necrosis factor- $\alpha$, interleukin- $1 \beta$, and interleukin- 8 . Acute-phase proteins and cytokines were measured by ELISA in 24 healthy pregnant women undergoing vaginal delivery or Cesarean section. Cord blood samples in addition to maternal blood were collected. SAA and CRP reached the maximum maternal serum levels 24 hours after delivery, while cytokines remained constant over time. SAA and CRP were significantly higher in maternal serum than in newborn's $(P<.001)$ at the moment of delivery. SAA and CRP, regardless of the type of delivery, reproduce the common pattern observed in most inflammatory conditions. Proinflammatory cytokine serum levels do not mirror the increase in SAA and CRP levels.
\end{abstract}

\section{INTRODUCTION}

C-reactive protein $(\mathrm{CRP})$ is an acute-phase protein whose levels in blood rise up to 1000 -fold in response to injuries, trauma, infection, inflammation, and neoplasia $[1,2,3,4]$. Because of the potential usefulness of CRP to diagnosing infection in pregnant women, many studies have described alterations of CRP during pregnancy, labor, and postpartum in normal conditions and disease. Humans have another important acute-phase protein besides CRP: serum amyloid A (SAA) [1, 2, 4, 5, 6, 7]. The determination of SAA has improved in recent years, prompting studies that attempt to establish comparisons with CRP $[1,7,8,9,10]$, as well as its usefulness in monitoring different clinical conditions $[2,4,5,8,9,11,12,13]$.

CRP and SAA display a similar pattern in most inflammatory diseases, reaching a maximum serum con-

Correspondence and reprint requests to Ana Campa, Departamento de Análises Clínicas e Toxicológicas, Faculdade de Ciências Farmacêuticas, Universidade de São Paulo, SP-CEP 05508-900, Brazil; anacampa@usp.br centration about 24 hours after the inflammatory process sets in and then slowly decreasing. SAA has been considered better than CRP to monitor or diagnose viral infections and noninvasive or early invasive bacterial infections $[7,11,12,13]$. An additional advantage of SAA seems to be its sensitivity in the diagnosis of transplant rejection, particularly in the case of renal grafts [14].

Here, we compare CRP with SAA in serial blood samples taken during vaginal and Cesarean delivery. Our interest in establishing normal values for the concentration of these two acute-phase proteins in labor and postpartum also led us to seek a correlation between acutephase proteins and some inflammatory cytokines. The reason for this investigation was based on our previous studies, which showed that SAA is a potent stimulus for the release of proinflammatory cytokines in leukocyte cultures $[15,16,17]$. Although some studies determined the concentration of cytokines in maternal and cord blood and their correlation with cervical dilatation [18], neonatal disease [19], gestational age newborn [20] and perinatal period [21], none of these studies tried to correlate cytokines with the acute-phase protein SAA. 
TABLE 1. Concentration of acute-phase proteins and cytokines in maternal serum upon admission for delivery, at the moment of delivery, and after delivery (24 and 60 hours) in vaginal delivery (VD), where $n=12$ and Cesarean section (CD), where $n=12$. Values are mean and standard deviation. nd denotes nondetectable. $*$ denotes that $P<.01$ compared to admission and moment of delivery and $\dagger$ denotes that $P=.01$ : CD differed from VD (variance analysis).

\begin{tabular}{|c|c|c|c|c|c|}
\hline Acute-phase proteins and cytokines & Delivery type & Admission & Delivery & $24 \mathrm{~h}$ & $60 \mathrm{~h}$ \\
\hline \multirow{2}{*}{$\mathrm{SAA}(\mu \mathrm{g} / \mathrm{mL})$} & VD & $7.1 \pm 4.4$ & $12 \pm 11$ & $230 \pm 32 *$ & $224 \pm 43^{*}$ \\
\hline & $\mathrm{CD}$ & $39 \pm 108$ & $12 \pm 12$ & $288 \pm 106^{*}$ & $325 \pm 110^{*}$ \\
\hline \multirow{2}{*}{ CRP (mg/dL) } & VD & $0.6 \pm 0.4$ & $0.9 \pm 0.7$ & $5.8 \pm 3.6^{*}$ & $2.8 \pm 1.5^{*}$ \\
\hline & $\mathrm{CD}$ & $1.8 \pm 2.4$ & $1.2 \pm 0.9$ & $11 \pm 5.3^{*, \dagger}$ & $9.4 \pm 4.8^{*, \dagger}$ \\
\hline \multirow{2}{*}{ TNF- $\alpha(\mathrm{pg} / \mathrm{mL})$} & VD & $3.9 \pm 3.4$ & $4.9 \pm 3.3$ & $6.0 \pm 3.7$ & $4.4 \pm 3.0$ \\
\hline & $\mathrm{CD}$ & $3.5 \pm 1.6$ & $3.8 \pm 1.8$ & $3.8 \pm 1.8$ & $3.1 \pm 1.7$ \\
\hline \multirow{2}{*}{$\mathrm{IL}-1 \beta(\mathrm{pg} / \mathrm{mL})$} & VD & nd & nd & nd & nd \\
\hline & $\mathrm{CD}$ & nd & nd & nd & nd \\
\hline \multirow{2}{*}{ IL-8 (pg/mL) } & VD & $8.0 \pm 15$ & $11 \pm 15$ & $32 \pm 31$ & $24 \pm 59$ \\
\hline & $\mathrm{CD}$ & $5.2 \pm 3.4$ & $6.8 \pm 6.2$ & $6.1 \pm 3.7$ & $6.6 \pm 5.2$ \\
\hline
\end{tabular}

\section{MATERIAL AND METHODS}

This study was approved by and followed the guidelines of the Ethical Committee of the Hospital Universitário and Faculdade de Ciências Farmacêuticas at the Universidade de São Paulo, Brazil. All the subjects were informed of the aims and procedures of the investigation and gave their written consent.

\section{Pregnant human subjects}

Healthy pregnant women volunteers were recruited for this study upon their admission for delivery at term. Entry criteria for all the subjects included no known health problems, and no autoimmune, infectious, or inflammatory diseases. The subjects had been in delivery at term (around 39 weeks), with rupture of membranes less than 6 hours prior to delivery. The first group comprised 12 women (aged $21 \pm 4$ years) in term labor who underwent a vaginal delivery. The second group consisted of 12 women (aged $26 \pm 7$ years) in term labor, who developed some form of complication during labor (dystocia or fetal distress) and had undergo Cesarean section delivery.

\section{Collection of blood}

Serum samples were collected from each volunteer at the moment of admission with signs of labor, immediately postpartum (with a concomitant cord blood specimen), 24 and 60 hours after delivery. The serum samples were stored at $-70^{\circ} \mathrm{C}$ until the determinations were made.

\section{Enzyme immunoassay for CRP, TNF- $\alpha$, IL-1 $\beta$, and IL-8}

Samples of serum were thawed and assayed in batches in a semiautomated analyzer (Immulite System, Diagnostic Products Corporation, Los Angeles, Calif) for chemiluminescent enzyme immunoassays (ELISA) using commercial kits. The analytical sensitivity and accuracy for CRP, TNF- $\alpha$, IL- $1 \beta$, and IL- 8 were $0.01 \mathrm{mg} / \mathrm{dL}, \mathrm{CV} 7.3 \%$; $1.7 \mathrm{pg} / \mathrm{mL}, \mathrm{CV} 3.2 \% ; 1.5 \mathrm{pg} / \mathrm{mL}, \mathrm{CV} 4.2 \%$; and $2.0 \mathrm{pg} / \mathrm{mL}$, CV 3.7\%, respectively.

\section{Enzyme immunoassay for SAA}

Samples of serum were diluted 1:20, 1:500 or 1:5000, and then tested through ELISA on 96-well microtiter plates (Phase Range Serum Amyloid A Assay, Tridelta Development Limited, Maynooth, Kildare, Ireland).

\section{Statistical analysis}

Since the data obtained were not symmetrically distributed, log-transformed results were used for statistical analysis in order to obtain approximately normal distribution. All analysis was performed using statistical software (SPSS version 8.0) and was evaluated by analysis of variance, $t$ test, and correlations.

\section{RESULTS}

The serum concentrations of SAA, CRP, TNF- $\alpha$, IL$1 \beta$, and IL- 8 in maternal blood at the moment of admission, during and after delivery were determined in two different groups: vaginal delivery (VD) and Cesarean delivery (CD) (Table 1). A parallel increase of SAA and CRP concentrations was observed at 24 and 60 hours postpartum, with maximum values at 24 hours $(P<.01)$. A difference was found between VD and CD $(P=.01)$ only for CRP; this difference was observed after 24 and 60 hours. The maternal serum concentration of TNF- $\alpha$, IL- $1 \beta$, and IL-8 remained constant during all the periods of collection, regardless of the type of delivery.

All the parameters measured in maternal blood at delivery were also determined in cord blood. Given that no differences were found in cord blood samples obtained in both VD and CD, the data were grouped and further compared with maternal serum (Figure 1). No correlation between maternal and cord blood values was found for any parameter. However, significant differences were observed in SAA, CRP, and TNF- $\alpha$ between maternal and cord blood. The concentrations of SAA and CRP were much higher in maternal blood than in cord blood $(P<.001)$. The concentration of TNF- $\alpha$ in cord blood was slightly higher than in maternal blood $(P<.05)$. 


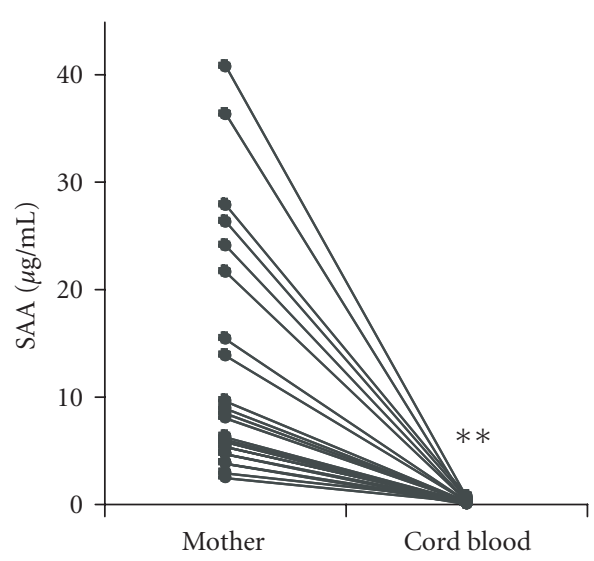

(a)

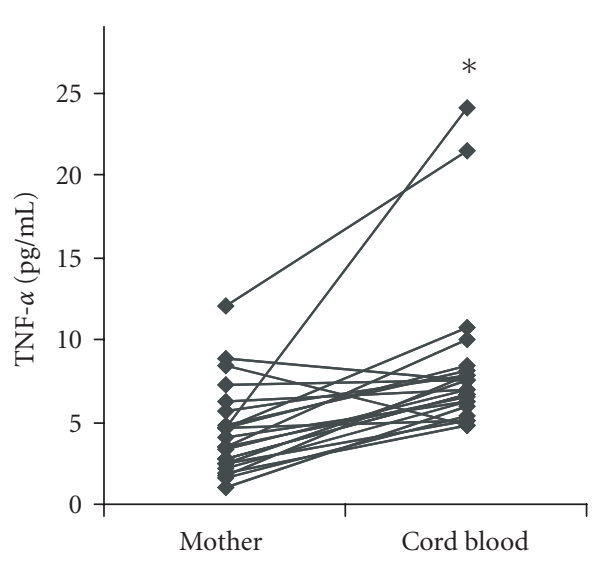

(c)



(b)



(d)

FIGURE 1. Concentration of SAA, CRP, TNF- $\alpha$, and IL- 8 in maternal and umbilical cord blood at delivery. The lines link values found in individual cases. ( $*$ denotes that $P<.05$ and $* *$ denotes that $P<.001$ for comparisons between the mother and cord blood groups).

\section{DISCUSSION}

The concomitant increase in SAA and CRP reproduces the common pattern observed in most inflammatory conditions [13]. The CRP values after delivery increased 10- to 20-fold when compared with those recorded upon admission, which were similar to the clinical reference value (lower than $0.5 \mathrm{mg} / \mathrm{dL}$ ). The increase in SAA during delivery was higher than CRP, which was 20 - to 30 -fold higher than upon admission (Table 1). The acute-phase response during delivery possibly protects the mother from the injury and mechanical effects of labor and these increased levels may be associated with host defense mechanisms. CRP increases bacterial phagocytosis and promotes the clearance of death cells [22]. SAA causes the priming of neutrophils, which contributes to bacterial death [23], and activates the synthesis of proinflam- matory cytokines $[15,16,17]$. Moreover, SAA seems to induce adhesion, migration, tissue infiltration, and secretion of neutrophil enzymes [5]. All these activities indicate an important role in host defense, prevention of infection, and repair.

The increase in acute-phase proteins observed in inflammatory conditions usually relates to the intensity of injuries. In delivery, the intensity of stress in $\mathrm{CD}$ may be higher than in VD. Our findings indicated that CRP discriminates between the two conditions, while SAA does not. Be that as it may, our data highlighted the difficulty of using CRP and SAA as markers of maternal infection in the postpartum period.

In earlier reports, we showed that SAA is a potent stimulus for the release of proinflammatory cytokines by leukocytes $[15,16,17]$. However, although SAA is high in maternal serum in the postpartum period, it does 
not correlate with serum concentration of cytokines. Cytokines are important in many stages of pregnancy and labor $[24,25,26,27]$, are locally produced in gestational tissues, and are present in cervico-vaginal and amniotic fluids. Nevertheless, these events are not reflected in the maternal serum, as revealed by the unaffected levels of TNF$\alpha$, IL-8, and IL- $1 \beta$ during delivery (Table 1 ). Therefore, the production and effect of cytokines seem to be strictly localized and the same may be at least partially true for SAA.

Even though SAA is active in leukocytes, when the SAA is bound to high-density lipoprotein (the form present in serum), it does not trigger a stimulatory effect on leukocytes [15]. A localized effect of SAA has been foreseen in tissues that express this protein, for example, placenta [28].

Although the concentration of SAA and CRP in the mother's serum at the moment of delivery is, in some cases, slightly higher than the basal level, in all the cases studied it was much higher than the levels found in cord blood. This finding reinforces the idea that there is a lack of transplacental transfer of these proteins during labor [1]. Thus, any increase in the newborn CRP and SAA levels may be a sign of infection or trauma. With regard to cytokines, it was observed that concentrations of TNF- $\alpha$ were higher in cord than in maternal blood in every case. The concentration of TNF- $\alpha$ in cord blood may originate exclusively from fetal and placental tissues and may contribute to neonatal host defense [29].

In conclusion, our findings show that the kinetics of the acute-phase proteins SAA and CRP, independently of the type of delivery, were similar and can not be correlated with maternal levels of cytokines. SAA and CRP could not be used to diagnose maternal infection in the postpartum period, but may be useful to diagnosing neonatal diseases.

\section{ACKNOWLEDGMENTS}

The authors are indebted to the gynecology and obstetrics staffs of the Hospital Universitário at USP, particularly to Maria Aparecida Chiea, Carlos Alberto Maganha, and Ana Lúcia Gaudenci Alves. This work was supported by Fundação de Amparo à Pesquisa do Estado de São Paulo (São Paulo), Conselho Nacional de Pesquisa, Desenvolvimento Científico e Tecnológico, Brazil.

\section{REFERENCES}

[1] de Villiers WJ, Louw JP, Strachan AF, Etsebeth SM, Shephard EG, de Beer FC. C-reactive protein and serum amyloid A protein in pregnancy and labour. Br J Obstet Gynaecol. 1990;97(8):725-730.

[2] Pizzini C, Mussap M, Plebani M, Fanos V. C-reactive protein and serum amyloid A protein in neonatal infections. Scand J Infect Dis. 2000;32(3):229-235.

[3] De Meeus JB, Pourrat O, Gombert J, Magnin G. Creactive protein levels at the onset of labour and at day 3 post-partum in normal pregnancy. Clin Exp Obstet Gynecol. 1998;25(1-2):9-11.

[4] Ceciliani F, Giordano A, Spagnolo V. The systemic reaction during inflammation: the acute-phase proteins. Protein Pept Lett. 2002;9(3):211-223.

[5] Urieli-Shoval S, Linke RP, Matzner Y. Expression and function of serum amyloid A, a major acute-phase protein, in normal and disease states. Curr Opin Hematol. 2000;7(1):64-69.

[6] Uhlar CM, Whitehead AS. Serum amyloid A, the major vertebrate acute-phase reactant. Eur J Biochem. 1999;265(2):501-523.

[7] Lannergard A, Larsson A, Kragsbjerg P, Friman G. Correlations between serum amyloid A protein and C-reactive protein in infectious diseases. Scand J Clin Lab Invest. 2003;63(4):267-272.

[8] Huttunen T, Teppo AM, Lupisan S, Ruutu P, Nohynek $\mathrm{H}$. Correlation between the severity of infectious diseases in children and the ratio of serum amyloid A protein and C-reactive protein. Scand J Infect Dis. 2003;35(8):488-490.

[9] Mayer JM, Raraty M, Slavin J, et al. Serum amyloid A is a better early predictor of severity than C-reactive protein in acute pancreatitis. Br J Surg. 2002;89(2):163-171.

[10] Maury CP. Comparative study of serum amyloid A protein and C-reactive protein in disease. Clin Sci (Lond). 1985;68(2):233-238.

[11] Arnon S, Litmanovitz I, Regev R, Lis M, ShainkinKestenbaum R, Dolfin T. Serum amyloid A protein in the early detection of late-onset bacterial sepsis in preterm infants. J Perinat Med. 2002;30(4):329-332.

[12] Lannergard A, Friman G, Larsson A. Serum amyloid A: a novel serum marker for the detection of systemic inflammatory response in cystitis. $J$ Urol. 2003;170(3):804-806.

[13] Nakayama T, Sonoda S, Urano T, Yamada T, Okada $\mathrm{M}$. Monitoring both serum amyloid protein A and C-reactive protein as inflammatory markers in infectious diseases. Clin Chem. 1993;39(2):293-297.

[14] Hartmann A, Eide TC, Fauchald P, et al. Serum amyloid A protein is a clinically useful indicator of acute allograft rejection. Nephrol Dial Transplant. 1997;12(1):161-166.

[15] Furlaneto CJ, Campa A. A novel function of serum amyloid A: a potent stimulus for the release of tumor necrosis factor-alpha, interleukin-1beta, and interleukin- 8 by human blood neutrophil. Biochem Biophys Res Commun. 2000;268(2):405-408.

[16] Ribeiro FP, Furlaneto CJ, Hatanaka E, et al. mRNA expression and release of interleukin- 8 induced by serum amyloid $\mathrm{A}$ in neutrophils and monocytes. $\mathrm{Me}$ diators Inflamm. 2003;12(3):173-178.

[17] Hatanaka E, Furlaneto CJ, Ribeiro FP, Souza GM, Campa A. Serum amyloid A-induced mRNA expression and release of tumor necrosis factor-alpha 
(TNF-alpha) in human neutrophils. Immunol Lett. 2004;91(1):33-37.

[18] Hebisch G, Grauaug AA, Neumaier-Wagner PM, Stallmach T, Huch A, Huch R. The relationship between cervical dilatation, interleukin- 6 and interleukin-8 during term labor. Acta Obstet Gynecol Scand. 2001;80(9):840-848.

[19] Dollner H, Vatten L, Halgunset J, Rahimipoor S, Austgulen R. Histologic chorioamnionitis and umbilical serum levels of pro-inflammatory cytokines and cytokine inhibitors. BJOG. 2002;109(5):534539.

[20] Dammann O, Phillips TM, Allred EN, et al. Mediators of fetal inflammation in extremely low gestational age newborns. Cytokine. 2001;13(4):234-239.

[21] Sarandakou A, Giannaki G, Malamitsi-Puchner A, et al. Inflammatory cytokines in newborn infants. $\mathrm{Me}$ diators Inflamm. 1998;7(5):309-312.

[22] Volanakis JE. Human C-reactive protein: expression, structure, and function. Mol Immunol. 2001;38(23):189-197.

[23] Hatanaka E, Pereira Ribeiro F, Campa A. The acute phase protein serum amyloid A primes neutrophils. FEMS Immunol Med Microbiol. 2003;38(1):81-84.

[24] Bowen JM, Chamley L, Mitchell MD, Keelan JA. Cytokines of the placenta and extra-placental membranes: biosynthesis, secretion and roles in establishment of pregnancy in women. Placenta. 2002;23(4):239-256.

[25] Keelan JA, Marvin KW, Sato TA, Coleman M, McCowan LM, Mitchell MD. Cytokine abundance in placental tissues: evidence of inflammatory activation in gestational membranes with term and preterm parturition. Am J Obstet Gynecol. 1999;181(6):1530-1536.

[26] Saito S. Cytokine cross-talk between mother and the embryo/placenta. J Reprod Immunol. 2001;52(12):15-33.

[27] Bowen JM, Chamley L, Keelan JA, Mitchell MD. Cytokines of the placenta and extra-placental membranes: roles and regulation during human pregnancy and parturition. Placenta. 2002;23(4):257273.

[28] Urieli-Shoval S, Cohen P, Eisenberg S, Matzner Y. Widespread expression of serum amyloid A in histologically normal human tissues. Predominant localization to the epithelium. J Histochem Cytochem. 1998;46(12):1377-1384.

[29] Nesin M, Cunningham-Rundles S. Cytokines and neonates. Am J Perinatol. 2000;17(8):393-404. 


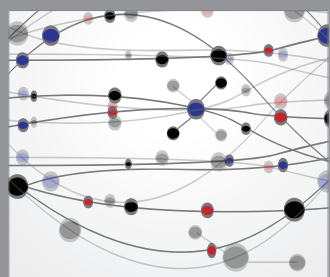

The Scientific World Journal
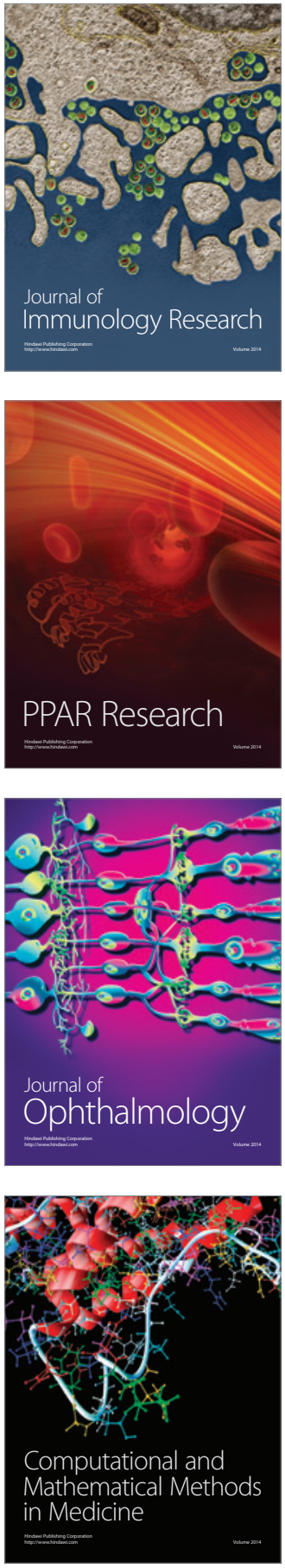

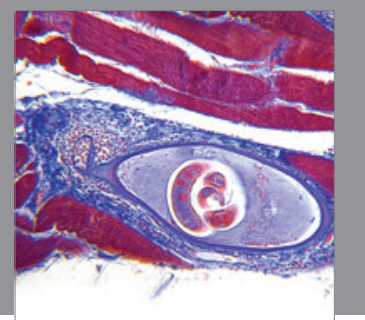

Gastroenterology

Research and Practice


\section{Hindawi}

Submit your manuscripts at

http://www.hindawi.com


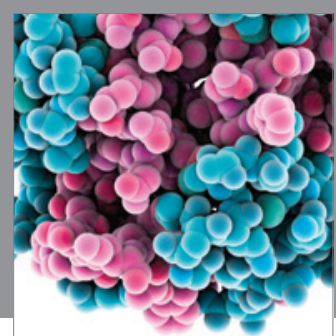

Journal of
Diabetes Research

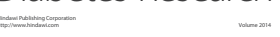

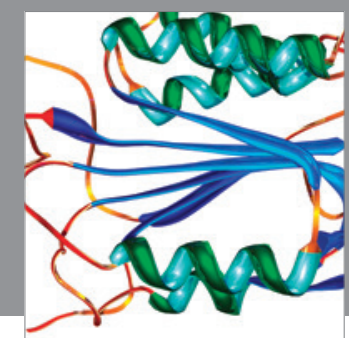

Disease Markers
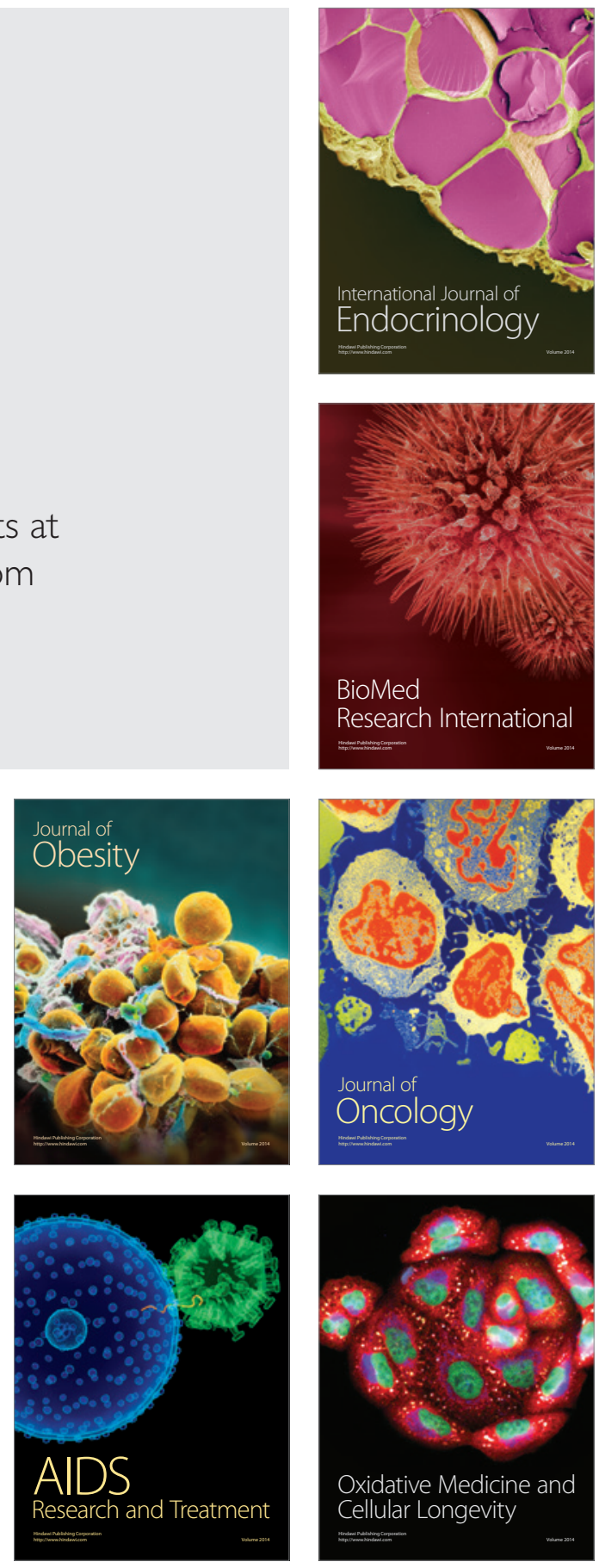